https://doi.org/10.18485/iipe_conv_conf.2021.ch9

\title{
THE SECOND ARMED CONFLICT IN NAGORNO-KARABAKH - CAUSES AND IMPLICATIONS
}

\author{
Ana Jović-Lazić ${ }^{1}$
}

\begin{abstract}
The article aims to contribute to the discourse on the latest armed conflict in Nagorno-Karabakh by analysing its causes and implications. Starting with the failure of the diplomatic process, it examines various factors, ranging from imbalances in local armed forces to broader changes in the region's geopolitical order that contributed to a shift in dynamics in this unresolved dispute and the outbreak of a new armed conflict between Armenia and Azerbaijan. Azerbaijan defeated Armenia decisively thanks to military superiority gained through increased military spending and political, military, and logistical assistance from Turkey. With this in mind, Turkey's role in the dynamics of this conflict is regarded as crucial. Furthermore, given Russia's traditional role as a mediator in unresolved conflicts in the postSoviet space, changes in Russian-Azerbaijani and Russian-Armenian relations are analysed as factors that influenced the creation of conditions in which Azerbaijan would feel strong enough to launch a new war. Russia's response is being considered in particular because, despite initial restraint, it has preserved its role as a key mediator in achieving peace in the region, seizing the opportunity to further strengthen it by deploying peacekeeping troops. Although the armistice agreement ended the war, the question of the disputed area's final status remained unresolved. Because this is a critical
\end{abstract}

\footnotetext{
${ }^{1}$ Ph.D., Senior Research Fellow, Institute of International Politics and Economics, Belgrade. anajovic@diplomacy.bg.ac.rs

The paper presents the findings of a study developed as a part of the research project "Serbia and Challenges in International Relations in 2021", financed by the Ministry of Education, Science, and Technological Development of the Republic of Serbia, and conducted by the Institute of International Politics and Economics, Belgrade.
} 
issue for both parties, a future flare-up of hostilities can only be avoided if Azerbaijan and Armenia achieve an agreement on the final political status of Nagorno-Karabakh.

Keywords: Nagorno-Karabakh, unresolved conflict, Azerbaijan, Armenia, Turkey, Russia, OSCE MINSK group

\section{INTRODUCTORY REMARKS}

Historically, the South Caucasus region has been home to a diverse range of ethnic groups, cultures, and religions. The geopolitical dynamics of the contemporary South Caucasus have been driven by the breakup of the Soviet Union and the desire of newly constituted nations to express their national identity and define their foreign policy. ${ }^{2}$ The ethnic-territorial dispute between the Armenians and the Azerbaijanis in Nagorno-Karabakh, which has been dormant for decades, is considered one of the most complicated and unresolved conflicts in the post-Soviet area. ${ }^{3}$ During the Soviet period, this area, primarily inhabited by Armenians, was an autonomous region inside the Azerbaijan Soviet Socialist Republic. Inter-ethnic tensions erupted during the disintegration of the Soviet Union, resulting in military confrontations between Azerbaijan and Armenia, which lasted until the mid-1990s. The Armenians triumphed in the armed conflict, occupying not only Nagorno-Karabakh but also the surrounding areas. Soon after, the OSCE established the MINSK Group as an international negotiation mechanism, but it was unable to persuade the governments of Azerbaijan and Armenia to reach an agreement. A compromise between Azerbaijan's claims to maintaining its sovereignty and territorial integrity and ethnic Armenians' aspirations to establish their own state in Nagorno-Karabakh based on the right to self-determination was not possible. Such distant positions, together with the policies of regional powers, generated complicated circumstances that did not give enough incentives to Azerbaijan and Armenia to adopt a peace strategy.

\footnotetext{
2 Sadi Sadiyev Saleh et al., "South Caucasus and a 'New Great Game': The Communication of Competition in Securitised International Relations," Journal of Contemporary European Studies 29, no. 2 (September 29, 2020): 282.

${ }^{3}$ Kavus Abushov, "Russian Foreign Policy towards the Nagorno-Karabakh Conflict: Prudent Geopolitics, Incapacity or Identity?," East European Politics 35, no. 1 (January 2, 2019): 72.
} 
Despite the ostensible peace, there were regular casualties as a result of periodic skirmishes between the conflicting sides along the line of contact. Nearly 300 people lost their lives during the so-called four-day conflict in April 2016, indicating that the situation was on the verge of "snatching control." That is what happened in September 2020, when Azerbaijan launched a military operation in Nagorno-Karabakh after years of developing military capabilities to reestablish sovereignty and reintegrate the disputed territory. Azerbaijan had significant diplomatic, logistical, and military support from Turkey, which, like Israel, supplied it with unmanned aerial vehicles that were crucial in determining the final outcome of the armed conflict. The Azerbaijani army had advanced deep into Nagorno-Karabakh, forcing Armenia to accept a ceasefire agreement reached through Russian mediation. Under the deal, Azerbaijan gained control of the majority of Nagorno-Karabakh, as well as the surrounding Azerbaijani territory, which was taken by Armenia during the first conflict in the early 1990s. At the same time, Russian peacekeepers were deployed to assist in maintaining the truce and carrying out the agreed-upon deal. The outcome of the war altered the situation on the ground, affecting the rest of the region. The fact that approximately 6,700 people, both soldiers and civilians, lost their lives during the conflict demonstrates the gravity of the situation. ${ }^{4}$

The renewal of the armed conflict in Nagorno-Karabakh has had farreaching regional and global security implications, dramatically affecting the decades-long status on the ground created by the end of the first conflict in the mid-1990s. As a result, several questions have arisen. What created the conditions for its escalation? What causes led to Azerbaijan's decisive victory, and what are the implications of such an outcome? How much did changed internal circumstances in Azerbaijan and Armenia contribute to such a result, and how much did the foreign policy of major regional countries, notably Turkey and Russia, influence it? What are the prospects for peace given that the eventual political status of Nagorno-Karabakh and the exact boundary dividing the two sides along the line of conflict remain undetermined under the truce agreement?

\footnotetext{
${ }^{4}$ Ian Davis. "Armed conflict and peace processes in Europe.", Stockholm International Peace Research Institute, SIPRI YEARBOOK 2021: Armaments, Disarmament and International Security. (S.L.: Oxford Univ Press, 2021). https://www.sipri.org/yearbook/2021/05.
} 
To answer these issues, the fundamental facts of Nagorno-Karabakh's first armed conflict and the blocked peace process will be presented. The article will next discuss Armenia's and Azerbaijan's new military confrontation. Following a brief overview of the conflict's dynamics and course, the focus will shift to the fundamental elements that contributed to the emergence of favourable conditions for its occurrence. In addition to the growing military capability disparity between Azerbaijan and Armenia, it will focus on other factors that influenced the renewal of the armed conflict. Special attention will be paid to the improvement of relations between Moscow and Baku, which is the result, above all, of the increased export of Russian weapons to Azerbaijan, as well as the loss of Moscow's trust in Yerevan after the so-called Velvet revolutions in Armenia in 2018. As Azerbaijan's traditional ally, Turkey was willing to openly back it not only politically and diplomatically, but also militarily, organizationally, and logistically, so Turkey's position will be considered as a significant factor that influenced the conflict's beginning and its outcome. Finally, the influence of the Second Armed Conflict in NagornoKarabakh on Moscow's objectives and the role as a traditional mediator in post-Soviet conflict resolution will be examined.

\section{ARMED CONFLICTS IN NAGORNO-KARABAKH \\ The dissolution of the Soviet Union and the first armed conflict in Nagorno-Karabakh}

Due to diverse historical, religious, and geopolitical influences, tensions between the Azerbaijanis and the Armenians over Nagorno-Karabakh have persisted for centuries. Cornell notes that the region's initial clashes date back to 1905, although there are differing perspectives on when they began and whether the Azeris or the Armenians are to blame. ${ }^{5}$ The opposing sides offer a range of historical reasons and evidence to support their claims. Thus, the region's early history has been overshadowed by contrasting historical interpretations, which are framed by the nationalist rhetoric of opposing sides. ${ }^{6}$

\footnotetext{
${ }^{5}$ Cornell, "Turkey and the Conflict in Nagorno-Karabakh: A Delicate Balance," Middle Eastern Studies 34, no. 1 (January 1998): 51-72.

${ }^{6}$ Tomáš Hoch, "The Roots of Ethno-Political Mobilization in Nagorno-Karabakh," The Soviet and Post-Soviet Review 47, no. 3 (July 3, 2020): 1-27, Adil Baguirov, "Nagorno-Karabakh:
} 
In any case, this conflict is inextricably linked to the political cartography of the early Soviet Union. During the Soviet era, beginning in 1921, NagornoKarabakh, predominantly inhabited by the Armenians, was an autonomous region within Soviet Azerbaijan. For years, the Armenians complained about cultural discrimination and economic neglect, attempting to bring NagornoKarabakh under Armenian direct authority. Due to the policy of Openness (Glasnost) under Gorbachev, these objections came to the fore. To take advantage of this policy, Armenian demands for secession from Azerbaijan and unification with the Armenian Soviet Socialist Republic became more prominent. Thus, in 1988, mass protests erupted in Yerevan, followed by counter-protests in Baku. ${ }^{7}$ To effectively manage such a complex situation, Moscow's strategy from 1988 to 1991 was primarily focused on protecting the Soviet Union's legitimacy. ${ }^{8}$ However, the accelerated degeneration of the state's ability to impose its will, particularly the Soviet state's lack of authority, created space for ethnic mobilization, the emergence of various national movements, and, finally, the outbreak of conflict. ${ }^{9}$ Despite the fact that the outbreak of the conflict was enabled by unstable circumstances caused by the collapse of the Soviet Union, the gradual ethno-political mobilisation of the Armenians and the Azeris. ${ }^{10}$

When Soviet Interior Ministry forces left Nagorno-Karabakh in December 1991, the dispute entered a military phase, escalating into an armed conflict between Azerbaijan and Armenia. By mid-1992, Armenian troops had established a land corridor connecting Nagorno-Karabakh and Armenia and

Competing Legal, Historic and Economic Claims in Political, Academic and Media Discourses," Journal of Muslim Minority Affairs 32, no. 2 (June 2012): 139-75, James J Coyle, Russia's Border Wars and Frozen Conflicts (Cham, Switzerland: Palgrave Macmillan, 2018), 208.

${ }^{7}$ Charles King, "The Benefits of Ethnic War: Understanding Eurasia's Unrecognized States," World Politics 53, no. 04 (July 2001): 529.

${ }^{8}$ Andrei A. Kazantsev et al., "Russia's Policy in the 'Frozen Conflicts' of the Post-Soviet Space: From Ethno-Politics to Geopolitics," Caucasus Survey 8, no. 2 (April 16, 2020):145.

${ }^{9}$ Vicken Cheterian, War and Peace in the Caucasus: Ethnic Conflict and the New Geopolitics (New York: Columbia University, 2008), p. 20; Christoph Zürcher, The Post-Soviet Wars: Rebellion, Ethnic Conflict, and Nationhood in the Caucasus (New York: New York University Press, 2009): 153.

${ }^{10}$ Tomáš Hoch, "The Roots of Ethno-Political Mobilization in Nagorno-Karabakh". 
had pushed the Azerbaijani army from Shushi, a key mountain from which it could attack Stepanakert. The conflict's acute phase concluded on April 16, 1993, with an Armenian victory. Armenian troops occupied not only NagornoKarabakh, but also $20 \%$ of the surrounding territory, or seven additional Azerbaijani districts, which served as a "seat belt" for this disputed region. The Russian Federation finally managed to secure peace in 1994 after multiple failed mediation attempts in the early 1990s. ${ }^{11}$ Specifically, the representatives of the Republic of Armenia and Azerbaijan, as well as Nagorno-Karabakh and the Russian representation in the OSCE Minsk Group, signed the "Bishkek Protocol" in early May 1994, which created a cease-fire. This protocol states categorically that the armed conflict not only caused irreparable losses for the Armenians and the Azeris but also had a significant influence on the whole area, the interests of other powers in the region, and, in general, considerably complicated the international situation. This protocol also supports all UN Security Council Resolutions 822, 853, 874, and 884, as well as the OSCE's objectives and specific decisions. The conflicting parties are also called upon to come to their senses and work intensively to confirm this by signing a reliable, legally binding agreement that provides a mechanism to ensure that military and hostile activities do not continue, withdraw troops from occupied territories, restore communication and return refugees. ${ }^{12}$ But although the "Bishkek Protocol" ended the conflict, it did not result in the withdrawal of forces or the repatriation of a substantial number of refugees and internally displaced persons. Meanwhile, the so-called Republic of Nagorno-Karabakh was created, with no country in the world, including Armenia, recognising its independence.

Also, following the cease-fire agreement, efforts to resolve this conflict were undertaken inside the OSCE Minsk Group, which was co-chaired by Russia, the United States, and France. However, the international community failed to persuade the leaders of Armenia and Azerbaijan to reach a compromise. The official positions of Baku and Yerevan remained very distant, while their completely incompatible demands became increasingly

${ }^{11}$ Charles King, "The Benefits of Ethnic War: Understanding Eurasia's Unrecognized States," 529, 532.

12 United Nations Peacemaker. "Bishkek Protocol | UN Peacemaker." peacemaker.un.org, May 5, 1994. https://peacemaker.un.org/armeniaazerbaijan-bishkekprotocol94. 
maximalist. The failure of the negotiations to progress resulted in numerous criticisms of the Minsk Group from both the international community and the conflicting parties, particularly Azerbaijan.

As a result, there was no lasting peace, and both countries continued to stockpile weapons. Under these conditions, the ethnic-territorial conflict between the Armenians and the Azerbaijanis over this territory has raged for decades, with regular skirmishes resulting in a number of casualties. Aggressive rhetoric and hate narratives have followed, resulting in a significant increase in tension on the contact line in recent years. ${ }^{13}$ Between 2014 and the outbreak of the second armed conflict in 2020, the number of incidents involving periodic exchanges of fire and casualties on both sides increased significantly. This demonstrates unequivocally that the region is far from peaceful and stable. Conflicts have become more frequent and intense, with several dozen people killed each year. An unexpected wave of violence, the so-called four-day war, in which several hundred people lost their lives in 2016, was a kind of test of the Armenian defence, as well as a warning to the international community that there was a real danger that the war in the region would escalate again. Regardless of the scale of the conflict escalation and its consequences, the international community, particularly the OSCE MINSK group, did not pay enough attention to this conflict, which contributed to the creation of favourable conditions for further aggression in the region. Furthermore, the fact that Azerbaijan managed to gain, albeit minor, territorial gains during the conflict demolished the so-called myth of Armenian soldiers' invincibility. ${ }^{14}$ Numerous artillery clashes broke out on the line of contact in mid-July 2020, resulting in the deaths of 17 soldiers on both sides and one civilian. This provoked demonstrations in Baku, with tens of thousands of people demanding a harsher response and the start of a new conflict to regain control of Nagorno-Karabakh. Tensions remained high following the clashes, with both sides blaming each other for the incidents.

${ }^{13}$ Philip Gamaghelyan and Sergey Rumyantsev, "The Road to the Second Karabakh War: The Role of Ethno-Centric Narratives in the Nagorno-Karabakh Conflict," Caucasus Survey 9, no. 3 (July 14, 2021): 1-17.

${ }^{14}$ Jarosław Kardaś, "The Unfreezing of the Nagorno-Karabakh Conflict through Changes to Azerbaijan's Security Policy," Refleksje, no. 1 (2017): 76. 


\section{The Second armed conflict in Nagorno-Karabakh}

Azerbaijan launched military action against Nagorno-Karabakh on September 27, 2020, dissatisfied with decades of stagnation in the negotiation process and pressed by local economic problems and the rise of nationalism. This large-scale conflict erupted following a difficult year marked by numerous armed incidents. Although the conflict lasted only a few weeks, it was intense and called into question the region's territorial authority status quo. It was clear very quickly that the balance of military forces had shifted dramatically in Azerbaijan's favour. With Turkey's support, Azerbaijan recaptured much of the territory it had lost in the previous conflict, while its forces advanced deep into the breakaway region and conquered Sushi, the region's second-largest and most strategically important city. Following the loss of Shushi in early November 2020, it appeared that Azerbaijani troops would capture the capital Stepanakert in a matter of hours rather than days.

Direct military intervention on Azerbaijan's side by Turkey and Syrian mercenaries threatened to jeopardise Russia's key role in resolving post-Soviet territorial disputes. Despite Turkey's increased influence, a truce was reached on November 9, 2020, thanks to Moscow's mediation, and all hostilities ceased, with both sides' forces remaining in their positions. This fact, in a sense, enabled Russia to maintain a key role in the ongoing process of resolving the Armenian-Azerbaijani conflict. ${ }^{15}$ There are also claims that a tacit unspoken agreement was reached based on Moscow's implicit consent to give Ankara a greater role in changing the circumstances of the unresolved Nagorno-Karabakh conflict, after which Turkey agreed to let Russia play a mediating role to end the conflict. ${ }^{16}$

With Russia mediating, Armenia and Azerbaijan signed a cease-fire agreement on November 10, 2020. Russian peacekeepers would be stationed in Nagorno-Karabakh to oversee the ceasefire along the line of contact and the Lachin corridor, which connects Nagorno-Karabakh and Armenia. ${ }^{17}$ The

${ }^{15}$ G. Avetikyan, "The 2020 War in Nagorno-Karabakh: The Regional Dimension," Pathways to Peace and Security 59, no. 2 (2020), 185.

${ }^{16}$ A. Valiyev and N. Gafarova, "New Big War in the South Caucasus and Prospects for Peace in Karabakh," Pathways to Peace and Security, no. 2 (2020): 167-80.

${ }^{17}$ The Russian Federation committed to deploying peacekeeping troops, including 1,960 personnel with arms, 90 armoured personnel carriers, 380 motor vehicles, and special equipment. It also ensured the return of internally displaced persons and refugees. 
parties also agreed to build new transportation links connecting the Nakhichevan Autonomous Republic to Azerbaijan's western regions, which is vital for that country. The ceasefire agreement will last for five years and will be automatically renewed unless one side notifies the other of its desire to withdraw at least six months before the scheduled date. ${ }^{18} \mathrm{~A}$ day after a tripartite ceasefire agreement was reached, Russia and Turkey signed a memorandum laying the groundwork for establishing a joint ceasefire monitoring centre. The centre was opened in the Agdam district of Azerbaijan in January 2021. It is expected to deal with the collection and processing of information on compliance with the ceasefire regime in Nagorno-Karabakh, with control carried out via unmanned aerial vehicles and other sources. ${ }^{19}$ Under the agreement, the major question about the future political status of Nagorno-Karabakh remains unanswered. Because this agreement did not resolve the disputed issue of Nagorno-Karabakh's political status, it is far from a guarantee that new hostilities will not erupt, because that risk exists until one of the parties is satisfied with its outcome. Nonetheless, it imposes significant, even temporary, constraints on new hostilities and will almost certainly have an impact on the reorganisation of the long-standing international framework for its resolution.

\section{FACTORS THAT CONTRIBUTED TO THE OUTBREAK OF THE SECOND NAGORNO-KARABAKH CONFLICT}

\section{The failure of the diplomatic process}

The OSCE Minsk Group-led negotiation process failed to persuade the leaders of Azerbaijan and Armenia to make mutual concessions. Despite the fact that considerable negotiations took place during this process and various solutions were offered to the opposing parties, a mutually acceptable

18 "Official Text of Nagorno Karabakh Armistice," armenpress.am, November 10, 2020, https://armenpress.am/eng/news/1034480.html.

${ }^{19}$ Sputnik Србија, “Отворен руско-турски центар за мониторинг примирја: Пут до стабилног мира у Карабаху," Sputnik Србија, 2021, https://rs.sputniknews.com/ 2021 0130/otvoren-rusko-turski-centar-za-monitoring-primirja-put-do-stabilnog-mira-ukarabahu-1124506798.html. 
agreement could not be reached. ${ }^{20}$ Russia is frequently blamed for the failure of peace talks. It is accused of supporting Nagorno-Karabakh separatism and monopolistic mediation in order to influence Armenian and Azerbaijani domestic and foreign policies. ${ }^{21}$ Partly this is because the region of NagornoKarabakh is so vital to both parties that it is regarded indivisible, and so settling its status would need a considerable sacrifice of both Armenian and Azerbaijani interests. ${ }^{22}$ The issue of the political status of Nagorno-Karabakh has always been the main point of contention between the two sides. Azerbaijan's position is that Armenian troops must immediately withdraw from the Nagorno-Karabakh region, that all displaced persons must be allowed to return, and that Azerbaijan's territorial integrity cannot be the subject of negotiations. Armenia, on the other hand, refuses to recognise Nagorno-Karabakh as an integral part of Azerbaijan, referring to the fact that it declared independence at the same time as Azerbaijan, and thus both are Soviet Union successors. In this context, Armenia demanded that the Nagorno-Karabakh government take part in discussions about the region's future, and it refused to hand over occupied territory to Azerbaijan or allow refugees to return to Nagorno-Karabakh so that their representatives could take part in status talks. ${ }^{23}$ Negotiations failed because, as Fowkes once observed, in an atmosphere of heightened nationalism, any attempt by political leaders on both sides to reach a compromise would almost certainly result in their political and, in some cases, physical death. ${ }^{24}$ According to some, any leader who is willing to compromise could be considered a traitor. ${ }^{25}$

${ }^{20}$ Ana Jović-Lazić, Sanja Jelisavac-Trošić, and Aleksandar Jazić, "Problem Nagorno Karabaha u svetlu bilateralnih odnosa članica Minsk grupe OEBS-a," Međunarodni problemi 63, no. 4 (2011): 583-612.

${ }^{21}$ Јовић-Лазић Ана, Односи између Европске уније и Руске Федерације: крај XX и почетак XXI века (Београд: Институт за међународну политику и привреду, 2015), 276-77.

22 Kavus Abushov, "Russian Foreign Policy towards the Nagorno-Karabakh Conflict: Prudent Geopolitics, Incapacity or Identity?".

${ }^{23}$ Ana Jović-Lazić and Ivona Lađevac, "Zamrznuti sukobi i pregovarački procesi u regionu Južnog Kavkaza," Međunarodna politika LXIV, no. 1152 (2013): 55-73.

${ }^{24}$ Ben Fowkes, Ethnicity and Ethnic Conflict in the Post-Communist World (New York: Palgrave, 2002), p. 137.

${ }^{25}$ Philip Remler et al., "OSCE Minsk Group: Lessons from the Past and Tasks for the Future," OSCE Insights 2020, 2020, 85-100, https://doi.org/10.5771/9783748922339-06. 
Because no agreement has been reached in years, there have been increasing calls to change the format of negotiations. Peace was coming under increasing pressure. Simultaneously, tensions and frustrations were rising, particularly on the Azerbaijani side. ${ }^{26}$ In addition to losing faith in the possibility of resolving the conflict through the international peace mechanism after years of inaction, Azerbaijan's decision to launch a military offensive was influenced by the fact that many of the factors that contributed to Armenia's victory changed. Thanks to energy revenues, Azerbaijan was able to significantly enhance and upgrade its military forces, strengthen relations with Turkey, and, most crucially, develop economic and military-technical cooperation with Russia. At the same time, in the aftermath of Armenia's political changes in 2018, there was growing scepticism about Yerevan's loyalty to Moscow.

\section{Weapons accumulation and the widening military gap between Azerbaijan and Armenia}

Following the end of the First War in Nagorno-Karabakh, Azerbaijan and Armenia engaged in some kind of arms race, resulting in the stockpiling of armaments in the region. Bearing in mind that, as a result of that armed conflict, the Armenian forces achieved significant territorial gains, they had no reason to start new hostilities. However, due to a considerable rise in Caspian Sea oil and gas revenues, Azerbaijan opted to increase budget allocations for weapons and military equipment modernization. In those conditions, Armenia's strategy was largely focused on deterring Azerbaijan from initiating a new conflict. Armenia continued to buy weapons, primarily from Russia, believing that participation in an arms race would reduce the risk of a new conflict erupting. Due to its poor economic situation, Armenia could only maintain parity in the arms race by obtaining armaments on extremely favourable terms from Russia as a result of its membership in the Collective Security Treaty Organization (CSTO). ${ }^{27}$ However, given that

\footnotetext{
${ }^{26}$ Sabine Freizer, "Twenty Years after the Nagorny Karabakh Ceasefire: An Opportunity to Move towards More Inclusive Conflict Resolution," Caucasus Survey 1, no. 2 (April 2014): 109-22.

${ }^{27}$ Sergey Minasyan, "The Nagorno-Karabakh Conflict in the Context of South Caucasus Regional Security Issues: An Armenian Perspectivet," Nationalities Papers 45, no. 1 (January 2017): 136.
} 
Azerbaijan's military budget had been steadily increasing since the start of the Baku-Tbilisi-Ceyhan (BTC) oil pipeline in 2006, Armenia gradually but steadily fell behind in this race.

Azerbaijan began to purchase weapons from different countries, including, inter alia, from Russia, Turkey, and Israel. As a result, over time, the military capabilities of the two sides began to diverge dramatically. The ability of Azerbaijani forces to conduct reconnaissance and precise attacks has greatly improved as a result of their possession of sophisticated weapon systems. The four-day armed confrontation in 2016 reflected this growth in military confidence in Azerbaijan, but only the Second War in NagornoKarabakh revealed Azerbaijan's true military supremacy over Armenia. A large number of drones in the military arsenal had a decisive influence on the victory of Azerbaijan. Various models of drones, including military modern equipment procured from Turkey and Israel, which were actively used during the conflict to detect, shoot, and attack Armenian defensive positions and armoured forces, allowed Azerbaijan to quickly gain, maintain primacy, and finally defeat Armenian forces. Also, Turkish military assistance was essential for the successful deployment of unmanned aerial vehicles in Azerbaijan, as well as precise artillery attacks. Azerbaijan also employed Israeli-made Harop kamikaze drones in addition to Turkish-made Barjaktar TB2-type attacking drones. ${ }^{28}$ Armenian troops, on the other hand, had little chance against them because they relied on an often outdated Russian weapon system.

Tactically, Azerbaijan also had Turkey's logistical support. At the beginning of the conflict, Azerbaijani forces disabled Armenian air defences before attacking Armenian armoured and infantry units with drones along the front lines. Such an offensive, with the widespread use of drones and technology, had an impact not only on the real military losses of Armenian forces but also on the general morale of Armenian soldiers.

\section{Improving relations between Azerbaijan and Russia}

After experiencing defeat in the First War in Nagorno-Karabakh, Azerbaijan realised the significance of Russia's role in the post-Soviet space in general, as

${ }^{28}$ Cory Welt and Andrew S. Bowen, "Azerbaijan and Armenia: The Nagorno- Karabakh Conflict" (Library of Congress Washington DC: Technical Report, Congressional Repor, January 7, 2021), https://apps.dtic.mil/sti/pdfs/AD1147494.pdf. 
well as in resolving this conflict in particular. Because the unresolved NagornoKarabakh issue directly threatens Azerbaijan's national interests, Baku has sought to pursue a pragmatic foreign policy that will develop relations with the West while also taking Russian interests in the region into account. Thus, in order to develop its oil and gas projects, Azerbaijan hired Western companies while attempting to maintain good relations with Russia. Energy export revenues have allowed Azerbaijan to significantly strengthen its economic position while also pursuing an independent foreign policy, avoiding existing security and political integration initiatives. ${ }^{29}$

As a result, Azerbaijan refused to join the Collective Security Treaty Organization and, later, the Eurasian Economic Union, which are both dominated by Russia. ${ }^{30}$ At the same time, because Azerbaijan has not expressed a desire to join the Euro-Atlantic integration process, Russia does not consider it a threat. Azerbaijan has also sought to strengthen economic ties with Russia, purchasing billions of euros in weapons from it. Relations between Azerbaijan and Russia have improved, notably since Vladimir Putin took power. In particular, Russia and Azerbaijan signed the Baku Declaration in 2001, which declares that enhancing Russian-Azerbaijani friendship and strategic partnership is an important factor in ensuring regional security. The willingness to expand bilateral cooperation in all areas was also confirmed, including economic, foreign policy, and military-technical cooperation. ${ }^{31}$ Two years later, in September 2003, Russia and Azerbaijan signed the Agreement on Military-Technical Cooperation, which entered into force in March 2005. It is expected to be achieved through the delivery of military products, materials, and technical means for the signatory states' defence and security needs, military-technical services, and military development and production cooperation. In addition, Russia and Azerbaijan agreed not to transfer

\footnotetext{
${ }^{29}$ Anar Valiyev and Narmina Mamishova, "Azerbaijan's Foreign Policy towards Russia since Independence: Compromise Achieved," Southeast European and Black Sea Studies 19, no. 2 (February 21, 2019): 269-271.

${ }^{30}$ Although it signed the Collective Security Treaty (CST) in Tashkent on May 15, 1992, Azerbaijan withdrew from it in 1999, while the signatory states agreed in 2002 to expand the CST into an international organization, the Collective Security Treaty Organization (CSTO).

31 "Бакинская декларация Российской Федерации и Азербайджанской Республики от 09 января 2001 - Docs.cntd.ru," docs.cntd.ru, accessed October 1, 2021, https://docs.cntd. ru/document/901783889.
} 
weapons and military equipment, as well as technical documentation for their production, to third parties, including international organizations, and to keep the information communicated in accordance with this agreement and its implementation confidential. ${ }^{32}$

Therefore, by signing and applying the provisions of this agreement, conditions have been created for Russia to become the leading supplier of weapons and other military equipment to Azerbaijan. As a result, the Azerbaijani army has a large stockpile of Russian-made military hardware, such as air defence systems, artillery, armoured vehicles, transport and combat helicopters, multiple rocket launchers, and tanks. ${ }^{33}$ In recent years, signed contracts for the purchase of weapons from Russia have amounted to 5 billion dollars. Over the last ten years, Russian supplies to Azerbaijan have included T-72 and T-90S tanks, BTR-80 armoured personnel carriers, "Smerch" and "Grad" multi-role missile systems, multi-role helicopters, anti-aircraft missile systems (SAM) S-300, and Radio-Electronic Warfare (EW). ${ }^{34}$ Aside from economic and military cooperation, there is diaspora interaction between Russian and Azerbaijani peoples, as well as active cooperation in the field of education. Thus, despite the centrifugal tendencies of the post-Soviet space and the specificities of Azerbaijan's foreign policy, including its confrontation with Armenia, Baku manages to maintain strategic relations with Moscow. ${ }^{35}$ All of this undoubtedly influenced Moscow's mild reaction and its relatively neutral position during the outbreak of the last conflict in Nagorno-Karabakh. ${ }^{36}$

32 "Соглашение между Правительством Российской Федерации и Правительством Азербайджанской Республики о военно-техническом сотрудничестве- Docs.cntd.ru," docs.cntd.ru, accessed October 1, 2021, https://docs.cntd.ru/document/901927006.

33 Pieter D. Wezeman, Alexandra Kuimov, Jordan Smith, Arms transfers to conflict zones: The case of Nagorno-Karabakh, SIPRI, 30 April 2021, https://www.sipri.org/commentary/topicalbackgrounder/2021/arms-transfers-conflict-zones-case-nagorno-karabakh.

${ }^{34}$ Александр Хроленко, "Военно-техническое сотрудничество Азербайджана и России: что на очереди?," Sputnik Азербайджан, 2019, https://az.sputniknews.ru/20191004/Voennotekhnicheskoe-sotrudnichestvo-Azerbaydzhana-i-Rossii-chto-na-ocheredi-421937021.html.

${ }^{35}$ В. А. Аватков, “Основы внешнеполитического курса Азербайджанской Республики на современном этапе," Контуры глобальных трансформаций: политика, экономика, право 13, no. 3 (August 20, 2020): 126.

${ }^{36}$ Araz Aslanlı, "Azerbaijan - Russia Relations: Is the Foreign Policy Strategy of Azerbaijan Changing?" (Turkish Policy Quarterly, 2010), https://esiweb.org/pdf/esi_turkey_tpq_vol9_ no3_araz-aslanli.pdf. 


\section{The Velvet Revolution in Armenia and the questionable loyalty of Yerevan to Moscow}

Historically, bilateral relations between Armenia and Russia have been very strong and diverse, but they have also been unbalanced due to Yerevan's overreliance on Moscow. Following the end of the First War in Nagorno-Karabakh and the establishment of the so-called independent republic in this region, Armenia began to view Russia as a security guarantor. Thus, the 102nd Russian base, with approximately 3,000 soldiers, has been stationed in Gyumri, Armenia, since 1995. Armenia joined the CST in 1993 and the CSTO in 2002, with the founding treaty stating that member states may be called to participate in armed conflict on the territory of any other CSTO member in the event of aggression. ${ }^{37}$ Furthermore, in accordance with a 2016 bilateral agreement, a single Russian-Armenian air defence system was established, as well as a united Russian-Armenian ground military force, the immediate task of which is to detect and repel potential threats from armed attacks on Armenia and Russia. ${ }^{38}$ There is also close cooperation, which enables Armenia to buy Russian weapons on very favourable terms. Also, the two countries have strong economic and energy relations, with Yerevan relying on Moscow for both the economy and energy supply. Given Armenia's unstable economic situation, this cooperation with Russia is critical. As a result of the unresolved conflict in Nagorno-Karabakh, the country's borders with Azerbaijan and Turkey have been closed, making it difficult to attract foreign direct investment. ${ }^{39}$

The Velvet Revolution in Armenia in 2018 triggered a series of political shifts in the country, affecting both its foreign policy and bilateral relations with Russia. Moscow was upset with the developments in Armenia because

37 “Договор о коллективной безопасности," odkb-csto.org, accessed October 11, 2021, https://odkb-csto.org/documents/documents/dogovor_o_kollektivnoy_bezopasnosti/.

${ }^{38}$ Eduard Abrahamyan, "Russia and Armenia Establish Joint Ground Forces," The Central AsiaCaucasus Analyst (Analytical Articles, December 16, 2016), https://www.cacianalyst.org/ publications/analytical-articles/item/13416-russia-and-armenia-establish-joint-groundforces.html.

${ }^{39}$ In 1993, Turkey blocked its border with Armenia to support Azerbaijan in the NagornoKarabakh conflict. Audrey L. Altstadt and Rajan Menon, "Unfrozen Conflict in NagornoKarabakh," Foreign Affairs, April 12, 2016, https://www.foreignaffairs.com/articles/armenia /2016-04-12/unfrozen-conflict-nagorno-karabakh. 
it considered the regime changes in street protests to be something that the West was supporting and organising in the post-Soviet area. The new Prime Minister, N. Pashinyan, sought to advance the importance of cooperation with Western partners, from whom Armenia expected financial and diplomatic assistance. In doing so, Armenian MPs in the Council of Europe's Parliamentary Assembly even voted against Russia's return to the organisation in June 2019. Despite the fact that the new leadership completely replaced the heads of the former government's security structures, which were loyal to the Kremlin, Armenia attempted to maintain the political and security benefits provided by Russia. Following the outbreak of the Second War in Nagorno-Karabakh, Pashinyan asked Russia's assistance as an ally under bilateral agreements between the two countries, emphasising that Azerbaijan's intervention posed a military threat to Russia's national and security interests. ${ }^{40}$ Russia, on the other hand, sought to stay restrained, hesitant to take the political risks of publicly supporting one side or another during the Second War in Nagorno-Karabakh. Furthermore, Russia considered that, as the power balance in the conflict shifted in Azerbaijan's favour, Armenia should be more engaged in its efforts to achieve a peace deal. In any case, Russia's ambiguous stance during the conflict undermined Yerevan's faith in Moscow, which likely affected the conflict's outcome. However, this will have little impact on future ties between Armenia and Russia, and Yerevan's reliance on Moscow will remain unchanged. This is a result of the region's geopolitical position as well as Armenia's economic and military weakness, which limits its foreign policy options.

In addition to the abovementioned factors that influenced the creation of conditions for a new flare-up of the conflict, an examination of regional powers' policies and interests, particularly those of Turkey and Russia, is critical for understanding its causes and implications.

\footnotetext{
${ }^{40}$ Agnieszka Miarka and Justyna Łapaj-Kucharska, "Armenian Foreign Policy in the Wake of
} the Velvet Revolution," European Politics and Society, May 25, 2021: 1-14. 


\section{THE INTERESTS OF REGIONAL POWERS IN THE CAUCASUS AND THEIR ROLE IN THE SECOND NAGORNO-KARABAKH CONFLICT}

\section{The interests and objectives of Turkey}

Turkey's relationship with the South Caucasus is not new, given the region's long history as part of the Ottoman Empire. The Caucasus drew the attention of not only the Ottoman Empire, but also modern Turkey. During the Cold War, this region served as a borderland between opposing blocs, and after its end, it became the area of the emergence of new states and local conflicts. ${ }^{41}$ Although Turkey attempted to enhance its influence in the area following the collapse of the Soviet Union, it has only recently begun to pursue a more assertive foreign policy and operate as an independent actor in international affairs.

Azerbaijan and Turkey are highly similar in terms of culture, language, and ethnicity. Because of these ties, Turkey has always been unwavering in its commitment to Azerbaijan's national interests, as well as developing military and economic cooperation and solidarity with Baku. Because of its energy reserves and the two countries' growing interdependence in this area, Azerbaijan has recently become critical to Turkey. Turkey's relationship with Azerbaijan has shifted to one of guaranteeing safe energy supplies from the Caspian Sea. In this regard, Turkey plays an important role in the BakuTbilisi-Ceyhan oil pipeline and the Trans-Anatomical Gas Pipeline (TANAP), both of which transport Azerbaijani energy to Turkey and Europe. Furthermore, Nagorno-Karabakh is critical to Turkey for a variety of reasons, the most important of which is its connection with Azerbaijan for access to the Caspian Sea. ${ }^{42}$

Turkey provided Baku with unprecedented diplomatic, political, military, and logistical support during the recent conflict in Nagorno-Karabakh. This demonstrated the significance of military cooperation in Azerbaijan-Turkey relations. It began with the signing of a military cooperation agreement in 1992, but it grew into a form of defence pact with the signing of the Strategic

${ }^{41}$ Слободан Јанковић, Вук Лазић, “Кавкаски вектор савремене спољне политике Турске,” in Конфрликтне зоне на постсовјетском простору и регионална безбедност, ed. Драган Петровић (Институт за међународну политику и привреду, 2021): 348.

${ }^{42}$ Stephen F. Larrabee, “Turkey's New Geopolitics," Survival 52, no. 2 (March 25, 2010): 157-80. 
Partnership and Mutual Support Agreement in 2010, offering mutual support in the event of a third-party attack. This agreement provides a legal foundation for future military and military-technical cooperation. It stipulates that if one of the parties is subjected to an armed assault or military aggression by a third state or group of states, all appropriate measures will be used, including the use of military force. According to the agreement, the parties will take all the necessary steps to build military infrastructure, complete armed forces training, and transfer essential weapons and military equipment. ${ }^{43}$ As a result of the agreement, Turkey and Azerbaijan were able to expand their military cooperation. Regular combined military exercises between the two sides have increased in recent years and have taken place in mainland Azerbaijan and the Nakhchivan exclave. ${ }^{44}$ Following the aforementioned armed incidents in midJuly 2020, in the midst of substantially heightened tensions, two-week military drills involving both Turkey's and Azerbaijan's ground and air forces were held. The official goal of the exercises was to assess their ability to react quickly, their combat readiness to conduct joint operations and to specify issues of cooperation between military headquarters. ${ }^{45}$ The military exercises in 2020 were notable not only for being the largest, but also for Turkey's sharing of experience in the deployment of unmanned aerial vehicles, multi-launch missile systems (MLRS), and air defence systems to Azerbaijan. ${ }^{46}$ TurkishArmenian ties, unlike those with Azerbaijan, are hampered by a bleak historical legacy, centuries of hatred, and diverging perspectives on critical regional issues, as Janković and Lazić pointed out. They also noted that Turkey had used

43 "Türkiye Cumhuriyeti ile Azerbaycan Cumhuriyeti Arasında Stratejik Ortaklık ve Karşılıklı Yardım Anlaşması" Resmi Gazete, May 28, 2011, https://www.resmigazete.gov.tr/eskiler /2011/05/20110528M1-30-1.pdf.

${ }^{44}$ Branch, Anthony R. "Armenia and the South Caucasus: A New Security Environment." Connections 17, no. 2 (2018): 54.

${ }^{45}$ Vasif Huseynov, "Azerbaijan, Turkey Hold Large-Scale Military Drills amidst Escalation of Tensions with Armenia," Jamestown (Eurasia Daily Monitor, Vol: 17 No: 121, August 14, 2020), https://jamestown.org/program/azerbaijan-turkey-hold-large-scale-military-drillsamidst-escalation-of-tensions-with-armenia/.

${ }^{46}$ Vasif Huseynov, "Azerbaijan-Turkey Strategic Alliance Deepens amid Recent Conflicts," Geopolitical Monitor, September 22, 2020, https://www.geopoliticalmonitor.com/ azerbaijan-turkey-strategic-alliance-deepens-amid-recent-conflicts. 
its unique geopolitical position to isolate Armenia not only economically, but also from regional energy and transportation projects and initiatives. ${ }^{47}$

There are claims that Turkey and Azerbaijan planned the war together since their military cooperation, shown in joint military drills and the procurement of drones, intensified many months before the conflict's formal beginning. In addition to military personnel and experts from Turkey, it also engaged mercenaries from Syria. ${ }^{48}$ It is notable that, in this way, Turkey became, for the first time, openly involved in an armed conflict in the postSoviet space, which has traditionally been considered a Russian interest zone..$^{49}$ Thus, Turkey demonstrated a clear willingness to expand its regional influence, and given that this strengthening of regional power resulted in a shift in regional balance at the expense of Russia, the renewed conflict in Nagorno-Karabakh highlighted the complexities of Turkey-Russia relations. On the one hand, Russia acknowledged that acceptance of Turkish-Azerbaijani military dominance and changes in the status quo in Nagorno-Karabakh were inevitable, which is why Turkey, despite not being a signatory to the agreement, was consulted throughout the peace talks. In addition, after the agreement was reached, Turkey and Russia formed a joint monitoring centre to oversee its implementation. ${ }^{50}$

Despite the fact that Turkey is not a member of the peacekeeping mission in Nagorno-Karabakh, it has demonstrated its importance in a region that was previously dominated primarily by the Russians. At the same time, Turkey has shown a readiness to respect Russian interests in the region, while Russia is prepared to accept a larger role for Turkey in the region if it believes it will contribute to achieving its strategic goals on other fronts. As a result, the rise of Turkey's influence at the expense of Russia might have a regional, as well

${ }^{47}$ Слободан Јанковић, Вук Лазић, “Кавкаски вектор савремене спољне политике турске," 355.

${ }^{48}$ Mason Clark and Ezgi Yazici, "Erdogan Seeks to Upend Kremlin-Backed Status Quo in Nagorno-Karabakh," JSTOR, 2020, http://www.jstor.org/stable/resrep26446.

${ }^{49}$ G. Avetikyan, "The 2020 War in Nagorno-Karabakh: The Regional Dimension," Pathways to Peace and Security 59, no. 2 (2020): 185.

${ }^{50}$ ehmed Fatih, "The Caucasus State Relations with Turkey (1991-2020)," in The Changing Perspectives and "New" Geopolitics of the Caucasus in the 21st Century, ed. Serdar Yilmaz and Murat Yorulmaz (Ankara: Astana Yayınları, 2021): 177. 
as a global, impact. ${ }^{51}$ However, because Turkey is not mentioned in the text of the trilateral ceasefire agreement, and its representatives are only expected to contribute to the work of the Ceasefire Monitoring Centre, a significant increase in Turkey's power has been avoided for now.

\section{The interests and objectives of Russia}

Due to its complexity and the large number of ethnic groups that inhabit it, maintaining stability and influence in the South Caucasus region has always been of great importance to Russia. Since the South Caucasus serves as a kind of "buffer zone" whose protection is crucial for the country's national security, Russia, using various instruments in the political, military, and economic sense, is trying to maintain a decisive influence in this region. Although, as Leppingwell once remarked, the collapse of the Soviet Union left Russia to search for new foundations for its security policy, its foreign policy towards the so-called near abroad remained assertive. ${ }^{52}$ Shashenkov cites the Russian leadership's belief that the renewal of some kind of integration and active policy in the near abroad are required to solve the problems that arose with the collapse of the USSR. As a result, it was actively involved in all of the armed conflicts that followed the collapse of the Soviet Union. Russia's involvement was reflected in, as he goes on to say, sponsored peace treaties and the establishment of military bases. Regardless of the argument that it is necessary to protect its citizens abroad, this exposes Russia to accusations that it threatens the sovereignty of its neighbours and pursues a neoimperialist policy. ${ }^{53}$

Russia is attempting to maintain a central position in unsolved post-Soviet disputes while limiting the impact of other parties in the region. ${ }^{54}$ In this

${ }^{51}$ Sinikukka Saari et al., "Russia and Turkey in the post-soviet neighbourhood: Uneasy Tango," JSTOR, 2021, http://www.jstor.org/stable/resrep34006.7.

52 John W. R. Lepingwell, "The Russian Military and Security Policy in the 'near Abroad,"' Survival 36, no. 3 (September 1994): 71-72.

${ }^{53}$ Maxim Shashenkov, "Russian Peacekeeping in the 'near Abroad,'” Survival 36, no. 3 (September 1994): 49.

${ }^{54}$ Ana Jović-Lazić and Jovanka Kuvekalović-Stamatović, "Permanent Neutrality of the Republic of Moldova - Strategy for Survival between Russia and NATO?," The Review of International Affairs 71, no. 1179 (2020): 21-53. 
context, there are opinions that the specifics of the Caucasus determine its security policy in this region. It originates from the fact that the security of Russia's North and South Caucasus regions is intertwined, which is why Moscow is concerned that instability and separatism in the southern part of the region might undermine the country's stability and territorial integrity. In addition to the so-called spillovers of instability, terrorism is regarded as a significant threat to national security.

Furthermore, the threat of the West projecting influence in the region through future NATO expansion is considered a security threat. This puts Russia, as well as other regional actors, under a significant amount of security pressure, forcing them to resort to military action and the so-called "hard power first" strategy. ${ }^{55}$ Some argue, however, that while Russia remains the region's most powerful military force, its ability to influence the region's situation is far less than previously thought. Rasizade went on to say that it was hampered not only by the physical barrier of the Greater Caucasus but also by the unstable situation in the North Caucasus. As a result, Moscow works hard to maintain strong ties with Armenians, as well as Abkhazians and others who could support Russian interests, in order to counterbalance the expanding political and economic influence of other regional powers, such as Turkey. ${ }^{56}$

When the first war in Nagorno-Karabakh ended, Russia, together with the United States and France, became the co-chair of the OSCE Minsk Group for resolving the conflict in Nagorno-Karabakh. Some think that Russia's peace support was primarily symbolic. As part of the previously outlined strategy to enhance its position in the Caucasus, Russia exploited this conflict to further its foreign policy aims by influencing both Armenia and Azerbaijan. There are opinions that Russia's support for peace was, above all, declarative. ${ }^{57}$ Thus, although it left part of its armed forces in Armenia after the end of the First War in Nagorno-Karabakh, which Yerevan saw as a kind of guarantee against

\footnotetext{
${ }^{55}$ Andrey Sushentsov and Nikita Neklyudov, "The Caucasus in Russian Foreign Policy Strategy," Caucasus Survey 8, no. 2 (May 3, 2020): 127-128.

${ }^{56}$ Rasizade, A. "Azerbaijan's Prospects in Nagorno-Karabakh." Mediterranean Quarterly 22, no. 3 (July 1, 2011): 230.

${ }^{57}$ Kavus Abushov, "Russian Foreign Policy towards the Nagorno-Karabakh Conflict: Prudent Geopolitics, Incapacity or Identity?".
} 
Turkish intervention in Nagorno-Karabakh, offering it the chance to set up its bases without compensation in June 1994, the situation is far from simple. ${ }^{58}$ Despite the development of strategic partnerships, close ties, and Armenia's membership in the CSTO, Russia has improved relations with Azerbaijan over time, as previously stated. Also, Russian officials have repeatedly stated at the official level that they support the territorial integrity of Azerbaijan and that they see their role only as a mediator.

Although it openly supported Armenia during the First Nagorno-Karabakh War, Russia attempted to remain neutral during the Second NagornoKarabakh War. In this context, Russia's reactions during the initial phase of the conflict were relatively mild, consisting of consultations, calls for a cessation of hostilities, and joint statements with the OSCE Minsk Group CoChairs, France, and the United States ${ }^{59}$ Russia countered the argument that, given Armenia's membership in the CSTO, it should be more openly involved in the conflict by claiming that the security guarantees arising from this agreement apply to Armenia, not Nagorno-Karabakh.

However, as the war progressed, the prospect of Azerbaijan's complete military victory forced Russia to change its strategy. Moscow could not allow Armenia to be completely defeated because losing an ally would mean losing credibility. Also, allowing Azerbaijan to reclaim all of its disputed territories would deprive Russia of one of its most important sources of influence in the region, which enabled Moscow to keep control over both countries. Given that Moscow is attempting to maintain its role as a major mediator between Baku and Yerevan in order to maintain its position that any resolution to the crisis requires its approval, Russia has increased its efforts to reach an agreement between the two countries. Simultaneously, it wanted a rapid deescalation of the conflict in Nagorno-Karabakh with as little Russian investment as possible. It was a chance for Azerbaijan and Turkey to capitalise on territorial gains and enhance their regional influence without fear of Russian interference. The fact that the six-week conflict concluded with

${ }^{58}$ John W. R. Lepingwell, "The Russian Military and Security Policy in the 'near Abroad", 71-72.

${ }^{59}$ Laurence Broers, "Perspectives | Did Russia Win the Karabakh War? | Eurasianet," eurasianet.org, November 17, 2020, https://eurasianet.org/perspectives-did-russia-winthe-karabakh-war. 
Russia's mediation and the deployment of its peacekeeping forces allowed it to maintain and secure its vital regional interests. In addition to keeping Azerbaijan from fully controlling Nagorno-Karabakh, Russia maintained its influence in Armenia, kept excellent ties with Azerbaijan (to which it supplies weaponry), and stopped Turkey from considerably increasing its influence in the South Caucasus. ${ }^{60}$ In any case, Russia is aware of Turkey's new position and the fact that settling the conflict in this region without taking into consideration Turkey's interests will be impossible.

\section{CONCLUDING REMARKS}

The Nagorno-Karabakh dispute between Azerbaijan and Armenia is one of the most long-running, violent, and complicated unsolved conflicts in the former Soviet Union. Because of internal Azerbaijani instability and Russian support, Armenia gained the first military conflict in Nagorno-Karabakh. Since the first cease-fire agreement was reached in the mid-1990s, numerous attempts have been made to find a diplomatic solution to this conflict. They could not provide any results, though, because both parties anticipated that their positions would improve with time. Azerbaijan believed that increasing its army would give it more influence over the Armenians, while Armenians in Nagorno-Karabakh believed that their self-proclaimed de facto independent country would eventually achieve international recognition. The triumph in the first armed conflict in Nagorno-Karabakh instilled in Armenia a false sense of military supremacy that lasted until the beginning of the new conflict in Nagorno-Karabakh. A new conflict demonstrated that deadlock in peace negotiations or a frozen crisis can swiftly evolve into a new cycle of aggression. Its outcome significantly changed the situation on the ground, imposing the need to consider the circumstances that altered the current balance of power, resulting in a decisive victory for Azerbaijan and Turkey's growing influence in the region, where Russia had a decisive influence.

Apart from the stalemate in the peace process, the accumulation of weapons in Armenia and Azerbaijan did not create conditions for lasting

\footnotetext{
${ }^{60}$ Wojciech Górecki, "A New Stage of the Conflict over Nagorno-Karabakh," OSW Centre for Eastern Studies, September 28, 2020, https://www.osw.waw.pl/en/publikacje/analyses/ 2020-09-28/a-new-stage-conflict-over-nagorno-karabakh.
} 
peace. Despite both sides amassing weapons, it was a significant improvement in Azerbaijan's military capabilities that contributed to the outbreak of a new conflict and determined its outcome. Thanks to high revenues from energy exports, Azerbaijan multiplied its military budget, which enabled it to invest significant economic resources in the military budget, especially in the procurement of sophisticated weapons, which, over time, when it comes to military capabilities, led to its superiority over Armenia. Contrary to Armenia, which, due to its economic situation, had little choice but to continue purchasing weapons from Moscow, where it could do so at very favourable terms thanks to its membership in the CSTO, Azerbaijan purchased modern weapons from different countries, mostly from Russia, Turkey, Belarus, and Israel. Furthermore, Russia has supplied roughly twothirds of Azerbaijan's major arms in the last ten years. A significant increase in the import of Russian weapons to Azerbaijan enabled Moscow to generate a large income, which at the same time led to the improvement of its relations with Baku. Azerbaijan's reason for adopting such a policy was to guarantee that Moscow kept a relatively neutral position in the case of a new breakout in the conflict with Armenia, thus protecting one of the most significant national interests and restoring the occupied territory. Furthermore, Armenia's political position in this conflict was influenced by the so-called Velvet Revolution, which brought pro-Western leadership in 2018, disrupting previous relations between Moscow and Yerevan.

In the second war in Nagorno-Karabakh, Turkey and Russia played a significant and complex role. It was affected by both historical and current ties and relationships between these regional powers and Azerbaijan and Armenia, as well as Russian-Turkish relations. Changes in regional players' foreign policy strategies, particularly Turkey's and, to a lesser extent, Russia's, influenced the outbreak of the armed conflict in Nagorno-Karabakh because they did not provide enough incentives for Azerbaijan and Armenia's leaders to pursue a policy of peacemaking. When the last conflict erupted, Turkey, Azerbaijan's most important ally, publicly supported the country on political and military levels. As a result, Russia struggled to keep its relations with Armenia and Azerbaijan intact, as well as its regional position, which appeared to be jeopardised by the Azerbaijani offensive and Turkey's hostile attitude. In such a complicated setting, it was evident that further escalation of the conflict would have substantial security implications. Despite these obstacles, Russia was able to maintain a significant influence on regional developments 
by reaching an agreement on a ceasefire and the deployment of its peacekeepers on the ground. At the same time, the outcome of the armed conflict shifted the power balance between Armenia and Azerbaijan on a local level, as well as Turkey and Russia on a regional level. Given that the political status of Nagorno-Karabakh remains an open international issue with significant potential for new conflicts, it can only be resolved through compromise, taking into account the interests of Russia and Turkey, which could have a decisive influence on Armenia-Azerbaijan reconciliation. Until a lasting solution is found, the Nagorno-Karabakh conflict will continue to constitute a substantial security concern, a considerable burden on Armenian and Azerbaijani political and economic progress, and a significant impediment to regional economic development and collaboration.

\section{BIBLIOGRAPHY}

Abrahamyan, Eduard. "Russia and Armenia Establish Joint Ground Forces." The Central Asia-Caucasus Analyst. Analytical Articles, December 16, 2016. https://www.cacianalyst.org/publications/analytical-articles/item/ 13416-russia-and-armenia-establish-joint-ground-forces.html.

Abushov, Kavus. "Russian Foreign Policy towards the Nagorno-Karabakh Conflict: Prudent Geopolitics, Incapacity or Identity?" East European Politics 35, no. 1 (January 2, 2019): 72-92. https://doi.org/10.1080/21 599165.2019.1579711.

Aslanlı, Araz. "Azerbaijan- Russia Relations: Is the Foreign Policy Strategy of Azerbaijan Changing?" Turkish Policy Quarterly, 2010. https://esiweb.org/ pdf/esi_turkey_tpq_vol9_no3_araz-aslanli.pdf.

Avetikyan, G. "The 2020 War in Nagorno-Karabakh: The Regional Dimension." Pathways to Peace and Security 59, no. 2 (2020): 181-91. https://doi.org/ 10.20542/2307-1494-2020-2-181-191, p. 185.

Baguirov, Adil. "Nagorno-Karabakh: Competing Legal, Historic and Economic Claims in Political, Academic and Media Discourses." Journal of Muslim Minority Affairs 32, no. 2 (June 2012): 139-75.

Bayramov, Agha. "Silencing the Nagorno-Karabakh Conflict and Challenges of the Four-Day War." Security and Human Rights 27, no. 1-2 (July 13, 2016): 116-27. 
Broers, Laurence. "Perspectives | Did Russia Win the Karabakh War? | Eurasianet." eurasianet.org, November 17, 2020. https://eurasianet.org/ perspectives-did-russia-win-the-karabakh-war.

Christoph Zürcher. The Post-Soviet Wars : Rebellion, Ethnic Conflict, and Nationhood in the Caucasus. New York: New York University Press, 2009.

Clark, Mason, and Ezgi Yazici. "Erdogan Seeks to Upend Kremlin-Backed Status Quo in Nagorno-Karabakh." JSTOR, 2020. http://www.jstor.org/stable/ resrep26446.

Cornell, Svante E. "Turkey and the Conflict in Nagorno Karabakh: A Delicate Balance." Middle Eastern Studies 34, no. 1 (January 1998): 51-72.

Coyle, James, Russia's Border Wars and Frozen Conflicts. Cham, Switzerland, Palgrave Macmillan, 2018.

Davis, lan. "Armed conflict and peace processes in Europe." Stockholm International Peace Research Institute. SIPRI YEARBOOK 2021: Armaments, Disarmament and International Security. S.L.: Oxford Univ Press, 2021, https://www.sipri.org/yearbook/2021/05

Fowkes, Ben. Ethnicity and Ethnic Conflict in the Post-Communist World. New York: Palgrave, 2002, p. 137.

Freizer, Sabine. "Twenty Years after the Nagorny Karabakh Ceasefire: An Opportunity to Move towards More Inclusive Conflict Resolution." Caucasus Survey 1, no. 2 (April 2014): 109-22.

Gamaghelyan, Philip, and Sergey Rumyantsev. "The Road to the Second Karabakh War: The Role of Ethno-Centric Narratives in the NagornoKarabakh Conflict." Caucasus Survey 9, no. 3 (July 14, 2021): 1-17.

German, Tracey. "The Nagorno-Karabakh Conflict between Azerbaijan and Armenia: Security Issues in the Caucasus." Journal of Muslim Minority Affairs 32, no. 2 (June 2012): 216-29.

Górecki, Wojciech. "A New Stage of the Conflict over Nagorno-Karabakh." OSW Centre for Eastern Studies, September 28, 2020. https://www.osw. waw.pl/en/publikacje/analyses/2020-09-28/a-new-stage-conflict-overnagorno-karabakh.

Hoch, Tomáš. "The Roots of Ethno-Political Mobilization in Nagorno-Karabakh." The Soviet and Post-Soviet Review 47, no. 3 (July 3, 2020): 1-27. 
Huseynov, Vasif. "Azerbaijan, Turkey Hold Large-Scale Military Drills amidst Escalation of Tensions with Armenia." Jamestown. Eurasia Daily Monitor, Vol. 17 No. 121, August 14, 2020. https://jamestown.org/program/ azerbaijan-turkey-hold-large-scale-military-drills-amidst-escalation-oftensions-with-armenia/.

Huseynov, Vasif. "Azerbaijan-Turkey Strategic Alliance Deepens amid Recent Conflicts." Geopolitical Monitor, September 22, 2020. https://www.geopoliticalmonitor.com/azerbaijan-turkey-strategic-alliance-deepens-amidrecent-conflicts.

Jović-Lazić, Ana, and Ivona Lađevac. "Zamrznuti sukobi i pregovarački procesi u regionu Južnog Kavkaza.” Međunarodna Politika LXIV, no. 1152 (2013): 55-73.

Jović-Lazić, Ana, and Jovanka Kuvekalović-Stamatović. "Permanent Neutrality of the Republic of Moldova - Strategy for Survival between Russia and NATO?" The Review of International Affairs 71, no. 1179 (2020): 21-53.

Jović-Lazić, Ana, Sanja Jelisavac-Trošić, and Aleksandar Jazić. "Problem Nagorno Karabaha u svetlu bilateralnih odnosa članica Minsk grupe OEBSa." Međunarodni Problemi 63, no. 4 (2011): 583-612.

Kardaś, Jarosław. "The Unfreezing of the Nagorno-Karabakh Conflict through Changes to Azerbaijan's Security Policy." Refleksje, no. 1 (2017): 67-82.

Kazantsev, Andrei A., Peter Rutland, Svetlana M. Medvedeva, and Ivan A. Safranchuk. "Russia's Policy in the 'Frozen Conflicts' of the Post-Soviet Space: From Ethno-Politics to Geopolitics." Caucasus Survey 8, no. 2 (April 16, 2020): 142-62.

King, Charles. "The Benefits of Ethnic War: Understanding Eurasia's Unrecognized States." World Politics 53, no. 04 (July 2001): 524-52.

Larrabee, Stephen F. "Turkey's New Geopolitics." Survival 52, no. 2 (March 25, 2010): 157-80.

Lepingwell, John W. R. "The Russian Military and Security Policy in the 'near Abroad."” Survival 36, no. 3 (September 1994): 70-92.

Mehmed Fatih. "The Caucasus State Relations with Turkey (1991-2020)." In The Changing Perspectives and "New" Geopolitics of the Caucasus in the 21st Century, edited by Serdar Yilmaz and Murat Yorulmaz. Ankara: Astana Yayınları, 2021, 177. 
Miarka, Agnieszka, and Justyna Łapaj-Kucharska. "Armenian Foreign Policy in the Wake of the Velvet Revolution." European Politics and Society, May 25, 2021, 1-14.

Minasyan, Sergey. "The Nagorno-Karabakh Conflict in the Context of South Caucasus Regional Security Issues: An Armenian Perspectivet." Nationalities Papers 45, no. 1 (January 2017): 131-39.

Özkan, Behlül. "Who Gains from the 'No War No Peace' Situation? A Critical Analysis of the Nagorno-Karabakh Conflict." Geopolitics 13, no. 3 (August 18, 2008): 572-99.

Rasizade, A. "Azerbaijan's Prospects in Nagorno-Karabakh." Mediterranean Quarterly 22, no. 3 (July 1, 2011): 72-94.

Remler, Philip, Richard Giragosian, Marina Lorenzini, and Sergei Rastoltsev. "OSCE Minsk Group: Lessons from the Past and Tasks for the Future." OSCE Insights 2020, 2020, 85-100.

Saari, Sinikukka, Stanislav Secrieru, Sinikukka Saari, and Dimitar Bechev. "Russia and Turkey in the post-soviet neighbourhood: Uneasy Tango." JSTOR, 2021. http://www.jstor.org/stable/resrep34006.7, 31

Sadiyev Saleh, Sadi, Elman Nasirov Khudam, Khayal Iskandarov Ibrahim, and Greg Simons. "South Caucasus and a 'New Great Game': The Communication of Competition in Securitised International Relations." Journal of Contemporary European Studies 29, no. 2 (September 29, 2020): 282-94.

Shashenkov, Maxim. "Russian Peacekeeping in the 'near Abroad." Survival 36, no. 3 (September 1994): 46-69.

Sushentsov, Andrey, and Nikita Neklyudov. "The Caucasus in Russian Foreign Policy Strategy." Caucasus Survey 8, no. 2 (May 3, 2020): 134-136.

Valiyev, A., and N. Gafarova. "New Big War in the South Caucasus and Prospects for Peace in Karabakh." Pathways to Peace and Security, no. 2 (2020): 167-80.

Valiyev, Anar, and Narmina Mamishova. "Azerbaijan's Foreign Policy towards Russia since Independence: Compromise Achieved." Southeast European and Black Sea Studies 19, no. 2 (February 21, 2019): 269-91.

Vicken Cheterian. War and Peace in the Caucasus : Ethnic Conflict and the New Geopolitics. New York: Columbia University, 2008, 20. 
Welt, Cory, and Andrew S. Bowen. "Azerbaijan and Armenia: The NagornoKarabakh Conflict." Library of Congress Washington DC: Technical Report, Congressional Repor, January 7, 2021. https://apps.dtic.mil/sti/pdfs/ AD1147494.pdf.

Аватков, В. А. "Основы внешнеполитического курса Азербайджанской Республики на современном этапе." Контуры глобальных трансформаций: политика, экономика, право 13, nо. 3 (August 20, 2020): 118-39.

Јанковић, Слободан, Вук Лазић. “Кавкаски вектор савремене спољне политике Турске." In Конфликтне зоне на постсовјетском простору и регионална безбедност, edited by Драган Петровић, 345-68. Институт за међународну политику и привреду, 2021.

Јовић-Лазић Ана, Односи између Европске уније и Руске Федерације : крај XX и почетак XXI века, Београд: Институт за међународну политику и привреду, 2015, 276-77

Србија, Sputnik. "Отворен руско-турски центар за мониторинг примирја: Пут до стабилног мира у Карабаху." Sputnik Србија, 2021. https://rs. sputniknews.com/20210130/otvoren-rusko-turski-centar-za-monitoringprimirja-put-do-stabilnog-mira-u-karabahu-11245067 98.html.

Хроленко, Александр. "Военно-техническое сотрудничество Азербайджана и России: что на очереди?” Sputnik Азербайджан, 2019. https://az. sputniknews.ru/20191004/Voenno-tekhnicheskoe-sotrudnichestvoAzerbaydzhana-i-Rossii-chto-na-ocheredi-421937021.html.

"Bishkek Protocol | UN Peacemaker." peacemaker.un.org, May 5, 1994. https://peacemaker.un.org/armeniaazerbaijan-bishkekprotocol94.

"Official Text of Nagorno Karabakh Armistice." armenpress.am, November 10, 2020. https://armenpress.am/eng/news/1034480.html.

"Türkiye Cumhuriyeti ile Azerbaycan Cumhuriyeti Arasında Stratejik Ortaklık ve Karşılıklı Yardım Anlaşması" Resmi Gazete, May 28, 2011, https://www.resmigazete.gov.tr/eskiler/2011/05/20110528M1-30-1.pdf.

"Бакинская декларация Российской Федерации и Азербайджанской Республики от 09 января 2001 - Docs.cntd.ru." docs.cntd.ru. Accessed October 1, 2021. https://docs.cntd.ru/document/901783889. 
"Договор о коллективной безопасности." odkb-csto.org. Accessed October 11, 2021. https://odkb-csto.org/documents/documents/dogovor_o_ kollektivnoy_bezopasnosti/.

“Соглашение между Правительством Российской Федерации и Правительством Азербайджанской Республики о военнотехническом сотрудничестве - Docs.cntd.ru." docs.cntd.ru. Accessed October 1, 2021. https://docs.cntd.ru/document/901927006. 